\title{
Analytical studies on Annabethi Chenthuram, A Siddha Herbomineral Formulations
}

\author{
P. RAJALAKSHMI*, R. GEETHA SUDEER, V. VADIVEL, C. S. SAHAYAM AND P. BRINDHA \\ Centre for Advanced Research in Indian System of Medicine (CARISM), SASTRA University, Thanjavur-613 401, India
}

\author{
Rajalakshmi, et al.: Analytical studies on Annabethi chenthuram
}

\begin{abstract}
In Siddha system of medicine, herbs, metals, minerals, hydrochemicals, arsenics and animal products are predominantly used for medicine preparations. Annabethi is a common hydrochemical drug, which is popularly known as green vitriol (chemical name is ferric sulphate). Naturally Annabethi is collected in hills and also synthesized, which is green in colour with crystal form, nauseous astringent taste and has solubility in water. It is commercially prepared by mixing iron wire with sulphuric acid and evaporating the solution to crystallization. Annabethi chenthuram is commonly used in Siddha system of medicine for treating anaemia, fever and dysentery. Even though some research studies have been conducted on Ayurvedic kasisa bhasma (similar to Annabethi chenthuram in Siddha), there is no scientific work carried out on the Annabethi chenthuram. Hence, the present research work was focused on the in-house preparation and characterization of Annabethi chenthuram. Annabethi chenthuram was prepared, physico-chemical parameters were analysed and characterized using Fourier-transform infrared spectroscopy, X-ray diffraction, X-ray fluorescence, scanning electron microscope and particle size analyzer. Physico-chemical parameters such as loss on drying (1.00 \%), total ash (65.94\%), water soluble ash (1.864\%) and acid insoluble ash (39.02 \%) were determined. Fourier-transform infrared spectra revealed an increase of iron content (peaks at 617 and 430 ) when compared to the raw drug. $X$-ray diffraction pattern confirmed the presence of $\alpha-F e_{2} O_{3}$ and absence of $\beta-\mathrm{Fe}_{2} \mathrm{O}_{3}$ in Annabethi chenthuram. X-ray fluorescence analytical data showed that the medicine contained iron $(66.46 \%)$ and iron oxide $(93.58 \%)$. These results provided scientific evidence for the conversion of iron sulphate into an edible and bioavailable form in Annabethi chenthuram.
\end{abstract}

Key words: Annabethi chenthuram, physico-chemical standards, FTIR, XRD, XRF, SEM

Siddha system of medicine is a unique system providing better cure for all chronic ailments like carcinoma, syphilis, respiratory diseases, infectious diseases, diabetes, dermatological cases and autoimmune disorders. The Siddha system includes not only medicine and alchemy but also yoga and philosophy. In Siddha system, 220 types of metals, mineral, arsenics and hydrochemicals are used for preparing medicines ${ }^{[1]}$. Annabethi contained the hydrochemical, ferric sulphate with the chemical formula of $\mathrm{Fe}_{2} \mathrm{SO}_{4} \cdot 7 \mathrm{H}_{2} \mathrm{O}^{[2]}$. In English, Annabethi is called as green vitriol or green copper or salts of steel. It is called in Tamil Annabethi, Sanskrit Kaaseesa, Telugu Annabhedi, Malayalam Turus, Kannada kaasisa, Hindi Hara tutia, Gujarathi Hara-kasis, Punjabi and Kashmiri San-i-sabz, Urdu Hirakashish, Latin Ferric sulphate, French Sulphate ferreux, German Schwefelsaures Eisenoxydul and Arabian Zaje-Asfara ${ }^{[3]}$. It is an antihaemorrhagic drug without any odour that reacts with acid, soluble in water

*Address for correspondence

E-mail: rajalakshmi@carism.sastra.edu

November-December 2017 and insoluble in alcohol ${ }^{[3]}$. According to Siddha system of medicine, Annabethi is classified based on colour into four types, black, yellow, green and white ${ }^{[1,3]}$. It is one of the 120 Uparasam (hydrochemicals) mentioned in Siddha Materia Medica (Gunapadam: Thathu, Seevavaguppu $)^{[1]}$. It reacts with air and becomes white in colour. It is a very common Siddha mineral drug available in herbal drug shops of Tamilnadu and used for iron based herbo-metallic preparations like Annabethi chenthuram, Vedi Annabethi chenthuram ${ }^{[1]}$, Annapavazha chenthuram and Kadukkai mathirai ${ }^{[4]}$. There are several processes mentioned in Siddha text for preparing this drug. One important method

This is an open access article distributed under the terms of the Creative Commons Attribution-NonCommercial-ShareAlike 3.0 License, which allows others to remix, tweak, and build upon the work non-commercially, as long as the author is credited and the new creations are licensed under the identical terms

Accepted 12 October 2017

Revised 03 April 2017

Received 17 August 2016

Indian J Pharm Sci 2017;79(6):987-993 
mentioned in ancient Siddha literature is dissolving the iron rods in sulphuric acid by the aid of heat and it must be used in medicine only after purification.

Annabethi is used for the treatment of anaemia, indigestion and eye diseases. It also used to treat venereal diseases, amenorrhea (absence of menstruation), leucorrhoea (white discharge from uterus), whooping cough, malarial fever, worm infestation and swelling. Externally used for herpes zoster, venereal ulcer, fistula, uterus prolapse and rectal prolapse ${ }^{[1]}$. It is considered in high esteem as a haematinic in cases of anaemia ${ }^{[4]}$. It is also given as a substitute for other preparations of iron. In certain cases of jaundice and anaemia, it is considered as a specific drug. It improves the colour and vigour of the body by enriching the blood. Due to its astringent properties, it is given in combination with other drugs in cases of dysentery, diarrhoea and haemorrhage ${ }^{[5]}$. For reducing the body tiredness or drowsiness detoxified Annabethi $(130 \mathrm{mg})$ is provided with 1 ounce of Andrographis paniculata decoction or same quantity of Trachyspermum ammi extract for 3 times per day ${ }^{[1,3]}$. For amenorrhoea and chronic constipation, one part of purified Annabethi is administered with 2 parts of Musamparam (Aloe vera latex) and ground with sufficient quantity of honey ${ }^{[6]}$. Therapeutically, it acts as a nutrient, astringent, emmenagogue (stimulates menstruation), deodorant, antihelminthic and antiperiodic (antagonizes the poison of periodic disorders like ague $)^{[1,7]}$.

'Chenthuram' is a category of medicine with reddish colour and powder form and it retain potency for $75 \mathrm{y}^{[4]}$. Formulary of Siddha medicine shows the usage of Annabethi chenthuram for treating fever, dysentery, amenorrhea and jaundice ${ }^{[7]}$, but major therapeutic use is anaemia. Annabethi chenthuram should be taken with honey in a dose of 65 to $130 \mathrm{mg}^{[8]}$. According to Narayanaswami ${ }^{[9]}$, ghee also can be used as a vehicle. Previously, Nisha Kumari et al. ${ }^{[10]}$ explained that it has antimicrobial activity and this medicine is proved to be non-toxic and also reduces SGPT level in animal model ${ }^{[2,11]}$. A human clinical trial revealed that this medicine is very much effective for sickle cell anaemia $^{[12]}$.

Even though some research studies have been conducted on Ayurvedic kasisa bhasma (Similar to Annabethi chenthuram in Siddha), there is no scientific work carried out on the Annabethi chenthuram. Hence, the present research was focused on the inhouse preparation and characterization of Annabethi chenthuram.

\section{MATERIALS AND METHODS}

\section{Preparation of Annabethi chenthuram:}

Annabethi (iron sulphate) was procured from local raw drug shop of Thanjavur, Tamilnadu. The Citrus limon fruit was bought from the vegetable market of Thanjavur. The drug was detoxified as per the methods mentioned in authentic Siddha text book ${ }^{[13]}$. Fresh juice of lemon was used for preparation. The common procedure of Annabethi chenthuram preparation involves detoxification, incineration, trituration and verification. For detoxification, Annabethi $(1 \mathrm{~kg})$ was dissolved in 11 of water and filtered through muslin cloth in order to remove the dust and other impurities. To the filtrate, 10 drops of sulphuric acid was added and this mixture was kept under sunlight until evaporated completely and formation of solids. Use of any one of herbal ingredients (lime juice, sour rice water, Mollugo lotoides plant juice) is recommended for the preparation of Annabethi chenthuram as per Siddha literature ${ }^{[1]}$ and in this study we have used lemon juice. Detoxified Annabethi $(500 \mathrm{~g})$ was taken and mixed with $500 \mathrm{ml}$ of lemon juice. This mixture was kept under shaded condition for $12 \mathrm{~h}$ and kept under sunlight till it fully dried. After drying, chenthuram was incinerated with 50 cow dung cakes for one time by traditional method (Pandri putam, fig. 1).

\section{Physicochemical analysis:}

Physiochemical standards were analysed in triplicate following the standard procedures ${ }^{[14,15]}$. The determination of the total ash content of raw Annabethi, detoxified Annabethi and Annabethi chenthuram was done by following the method of Joshi and Aeri ${ }^{[16]}$. Powdered drug ( $1 \mathrm{~g})$ was added to a pre-weighed silica crucible and heated in the muffle furnace at $400^{\circ}$ for about $3 \mathrm{~h}$. Then the crucible was safely placed in a desiccator and allowed to cool to room temperature and the weight was finally measured. Percent weight of the total ash was calculated using the formula: weight of the ash/weight of the drug $\times 100$. Percent acid insoluble ash was calculated using the formula: weight of the residue/weight of the powder $\times 100$, where the weight of the residue is the net weight of ash. The water soluble extractives of the samples were analysed according to the same methodology. Dry powder $(1 \mathrm{~g})$ was taken in a beaker and $50 \mathrm{ml}$ of water was added in and shaken well manually. The beaker was kept aside for $24 \mathrm{~h}$ and thereafter $10 \mathrm{ml}$ of the solution was taken and kept in hot air oven at $105^{\circ}$. Finally the percent weight of the extract is calculated using the same formula. 

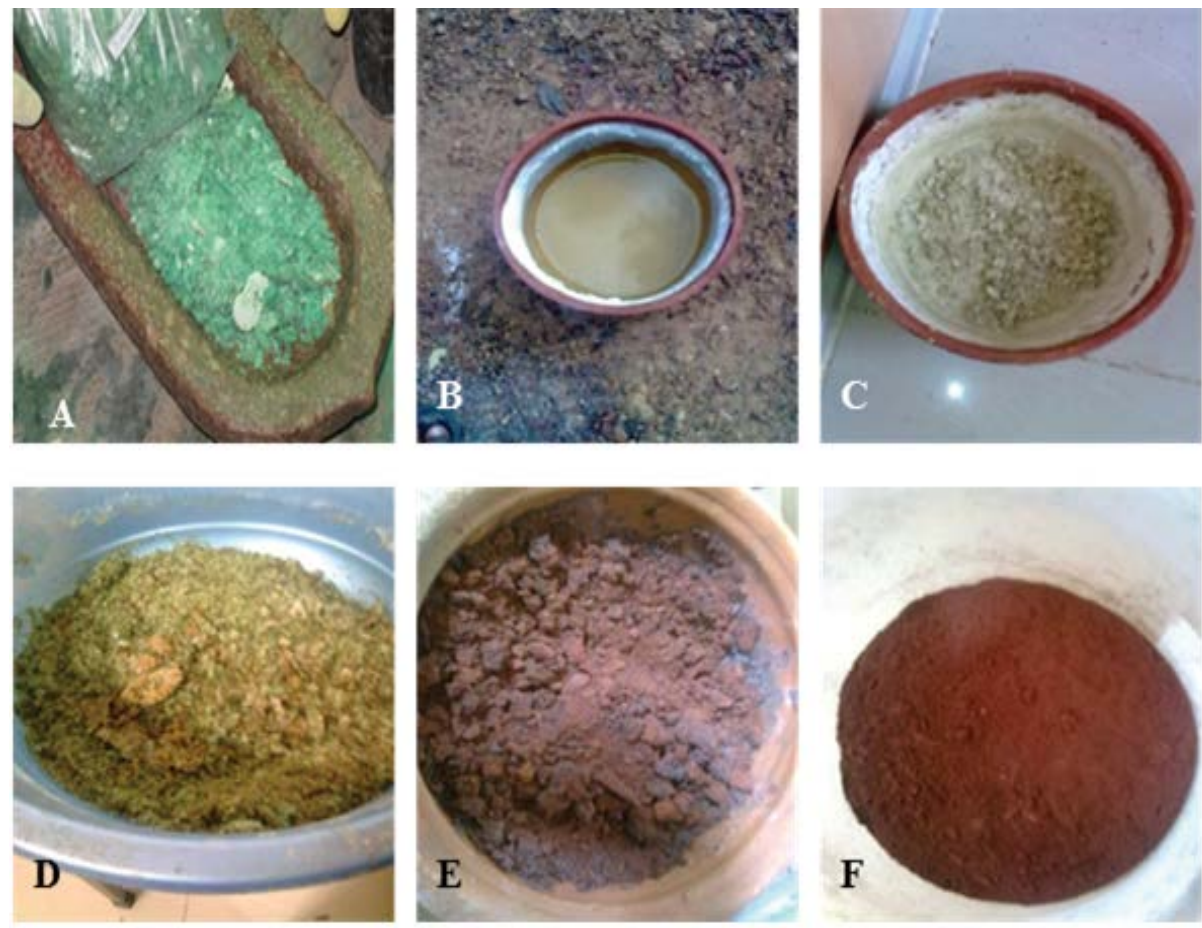

Fig. 1: Preparation of Annabethi chenthuram

A: Raw Annabethi, B: water dissolved Annabethi, C: purified Annabethi, D: Annabethi with lemon before putam, E: Annabethi chenthuram after putam, F: Annabethi chenthuram after trituration

The loss on drying (LOD) was estimated by taking $1 \mathrm{~g}$ of powdered drug in a pre-weighed dish and placed in the hot air oven at a temperature of $105^{\circ}$ and the LOD was calculated by using the formula: weight of the dish before heating-weight of the dish after heating/weight of the sample $\times 100$.

\section{Instrumental analysis:}

Raw and final drugs were analysed between 4000$400 \mathrm{~cm}^{-1}$ in the Fourier-transform infrared (FTIR) spectrometer (Spectrum100, Perkin Elmer, USA). The raw Annabethi and Annabethi chenthuram were examined from $10-60^{\circ}(2 \theta)$ with a step size of $0.01^{\circ}$ using an X-ray diffractometer (XRD, D8 Focus, Bruker, Germany), by irradiating with $\mathrm{Cu}-$ $\mathrm{K} \alpha$ radiation. The surface morphology of the drugs was studied qualitatively using a cold field emission scanning electron microscope (SEM, JSM6701F, Jeol, Japan). The sample was mounted on a brass stub and sputter coated with platinum and introduced into the specimen chamber and imaging was carried out at an acceleration voltage of $3 \mathrm{kV}$. The elemental composition of Annabethi chenthuram was determined using a X-ray fluorescence (XRF) spectrometer (S8 Tiger, Bruker AXS, Germany) using a $4 \mathrm{~kW}$ rhodium anode X-ray tube. Determination of average particle size of raw Annabethi and Annabethi chenthuram were carried out by the Microtrac particle size analyser that uses three precisely placed red laser diodes to accurately characterize particles. The patented TriLaser system provides accurate, reliable and repeatable particle size analysis for a diverse range of applications by utilizing the proven theory of Mie compensation for spherical particles and the proprietary principle of Modified Mie calculations for non-spherical particles. The S3500 measures particle size from 0.02 to 2800 microns (Microtrac Blue wave, S3500, USA).

\section{RESULTS AND DISCUSSION}

Iron deficiency is the most common type of anaemia in India, which is due to decrease in the haemoglobin (Hb) level. Decrease in the $\mathrm{Hb}$ intensity may disrupt the normal lifespan of red blood cells synthesized in the bone marrow and liver ${ }^{[17]}$. Siddha literature denotes that the cause for anaemia are excessive intake of salty, sour food items, toxic foods, liver disorders, bleeding piles, blood vomiting, polymenorrhagia and dysentery ${ }^{[5]}$. In Siddha system, Annabethi chenthuram is prescribed as excellent medicine for anaemia. Even though this drug is commonly used for long time, till date no scientific analytical works have been done to reveal the chemical composition of this drug. Hence, in this present work, we have determined the physico-chemical standards and surface characteristics of Annabethi chenthuram for the first time. 
Central Council for Research in Ayurveda and Siddha (CCRAS), Department of AYUSH, New Delhi given some analytical specifications for chenthuram $^{[18]}$. The physicochemical properties of raw, detoxified and final drug of Annabethi were investigated and the results are given in Table 1. The colour and taste characteristics were changed during detoxification and final drug preparation when compared to raw Annabethi, whereas no change was observed in odour.

LOD test indicates the amount of volatile matter (i.e. moisture drying off from the drug). The LOD of raw, detoxified and final drug of Annabethi was 25.91, 17.20 and $1.00 \%$ (Table 1), respectively, which shows the presence of high level of water content in the raw Annabethi.

But during detoxification and the final drug preparation, the moisture content was significantly reduced. The LOD level of final drug is equal to the standard limit of Pharmacopoeial standards for Ayurveda ${ }^{[19]}$. Total ash content was high $(65.94 \%)$ in final product of Annabethi, which indicates that this drug was prepared from non-volatile inorganic material.

The remaining portion (34.06\%) of chenthuram composed of combustible organic matter (sulphur), which might be evaporated under high temperature. Acid-insoluble ash was high in chenthuram compared

TABLE 1: PHYSICOCHEMICAL PROPERTIES OF RAW, DETOXIFIED AND FINAL DRUG OF ANNABETHI

\begin{tabular}{|c|c|c|c|}
\hline $\begin{array}{l}\text { Name of the } \\
\text { test }\end{array}$ & $\begin{array}{c}\text { Raw } \\
\text { Annabethi }\end{array}$ & $\begin{array}{l}\text { Detoxified } \\
\text { Annabethi }\end{array}$ & $\begin{array}{c}\text { Annabethi } \\
\text { chenthuram }\end{array}$ \\
\hline Colour & Green & $\begin{array}{l}\text { Whitish } \\
\text { yellow }\end{array}$ & $\begin{array}{l}\text { Brown } \\
\text { coloured } \\
\text { powder }\end{array}$ \\
\hline Odour & Odourless & Odourless & Odourless \\
\hline Taste & $\begin{array}{l}\text { Astringent } \\
\text { taste }\end{array}$ & $\begin{array}{l}\text { Sour with } \\
\text { astringent } \\
\text { taste }\end{array}$ & $\begin{array}{c}\text { No } \\
\text { characteristic } \\
\text { taste }\end{array}$ \\
\hline $\begin{array}{l}\text { Loss on drying } \\
\text { (LOD, \%) }\end{array}$ & 25.91 & 17.20 & 1.00 \\
\hline Total ash (\%) & 31.57 & 33.58 & 65.94 \\
\hline $\begin{array}{l}\text { Water soluble } \\
\text { ash (\%) }\end{array}$ & 0.518 & 0.958 & 1.864 \\
\hline $\begin{array}{l}\text { Acid insoluble } \\
\text { ash (\%) }\end{array}$ & 11.40 & 15.64 & 39.02 \\
\hline
\end{tabular}

The colour and taste characteristics were changed during detoxification and final drug preparation when compared to raw Annabethi, whereas no change was observed in odour. LOD test indicates the amount of volatile matter (i.e. moisture drying off from the drug) to raw and detoxified annabethi because of the inorganic material and this is in agreement with the previous findings on insoluble nature of inorganic matters in acid medium ${ }^{[20]}$. Previously Yadav and Debnath ${ }^{[21]}$ carried out analysis in the traditionally prepared Kasisa Bhasma and found 86.85-92.94\% of total ash content.

FTIR spectra of raw Annabethi showed the presence of huge $\mathrm{OH}$ stretch around $3200 \mathrm{~cm}^{-1}$ (fig. 2). Peak at $1623 \mathrm{~cm}^{-1}$ showed the presence of carbonyl groups. Peaks at 1147 and $1099 \mathrm{~cm}^{-1}$ showed the presence of $\mathrm{SO}_{4}$. Peaks at 617 and $430 \mathrm{~cm}^{-1}$ showed the presence of Fe-O peaks. Annabethi chenthuram showed the presence of Fe-O peaks at 827, 664, 624, 527 and $478 \mathrm{~cm}^{-1}$. Peaks at 1179, 1149, 1085 and $1006 \mathrm{~cm}^{-1}$ showed the presence of $\mathrm{SO}_{4}$ vibrations. Over all, both raw Annabethi and Annabethi chenthuram showed the presence of $\mathrm{Fe}-\mathrm{O}$ and $\mathrm{SO}_{4}$. However, intensity of Fe-O peaks was more in Annabethi chenthuram compared with raw Annabethi (fig. 2). Similarly, FTIR characterization was done for related kanta chenduram $^{[22]}$, Muthuchippi parpam ${ }^{[23]}$ and Varatika bhasma $^{[24]}$.

XRD spectra of raw Annabethi and Annabethi chenthuram showed the presence of peaks at 33.14, 37.17, and 47.21 $\AA$ which represent the presence of $\mathrm{FeS}_{2}$ in Annabethi chenthuram. Moreover, presence of $\beta-\mathrm{Fe}_{2} \mathrm{O}_{3}$ is also evidenced by the presence of peaks at $22.56,27.43,30.46$ and $44.36 \AA$ Á. Furthermore, peaks at $24.38,35.1,39.94$, and $50.93 \AA$ represent the presence of $\alpha-\mathrm{Fe}_{2} \mathrm{O}_{3}$ in the raw sample.

Though the Annabethi chenthuram showed the presence of traces of $\mathrm{FeS}_{2}$, the peaks at 35.44, 41.13, 54.34 and $57.9 \AA$ represent the presence of $\alpha-\mathrm{Fe}_{2} \mathrm{O}_{3}$ and absence of $\beta-\mathrm{Fe}_{2} \mathrm{O}_{3}$. Hence it is clear that the preparation process actually increased the percentage of $\alpha-\mathrm{Fe}_{2} \mathrm{O}_{3}$ and removal of $\beta-\mathrm{Fe}_{2} \mathrm{O}_{3}$ (fig. 3). Similarly, XRD characterization was done for related kanta chenduram and vanga Bhasma ${ }^{[22,25]}$.

$\mathrm{XRF}$ analysis, it is observed that so many elements are present in Annabethi chenthuram apart from the iron and sulphate (Table 2). Some of the elements such as iron, sulphur, copper and zinc are playing a major therapeutic role in Annabethi chenthuram. Level of oxide form of iron $\left(\mathrm{Fe}_{2} \mathrm{O}_{3}\right)$ was found to be higher (93.58\%) in Annabethi chenthuram when compared to elemental form $(66.46 \%)$. Similar trend was noted in the case of sulphur, manganese, potassium, aluminium, chromium, magnesium, sodium, copper, phosphorous, 


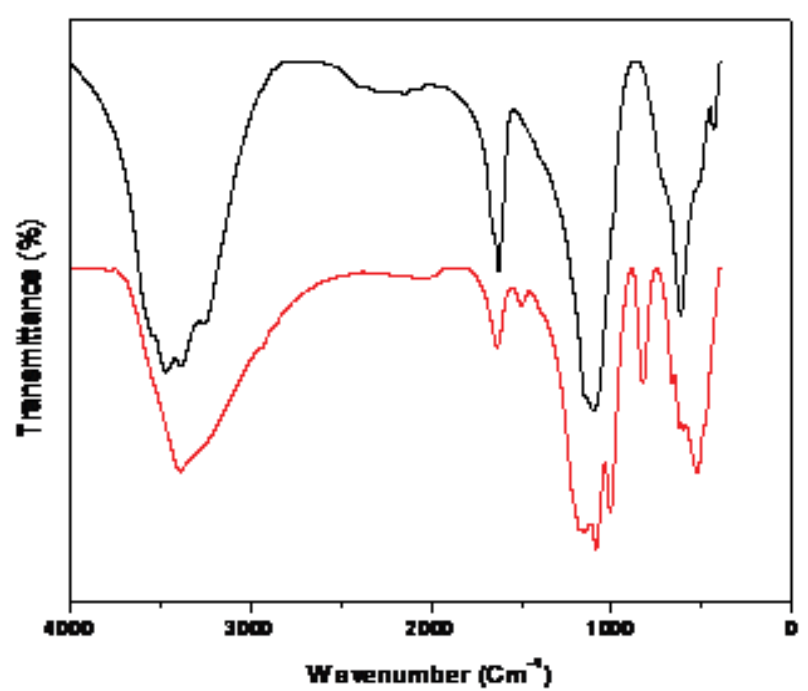

Fig. 2: FTIR spectra of raw Annabethi and Annabethi chenthuram

- Raw Annabethi; - Annabethi chenthuram. Both raw Annabethi and Annabethi chenthuram showed the presence of $\mathrm{Fe}-\mathrm{O}$ and $\mathrm{SO}_{4}$

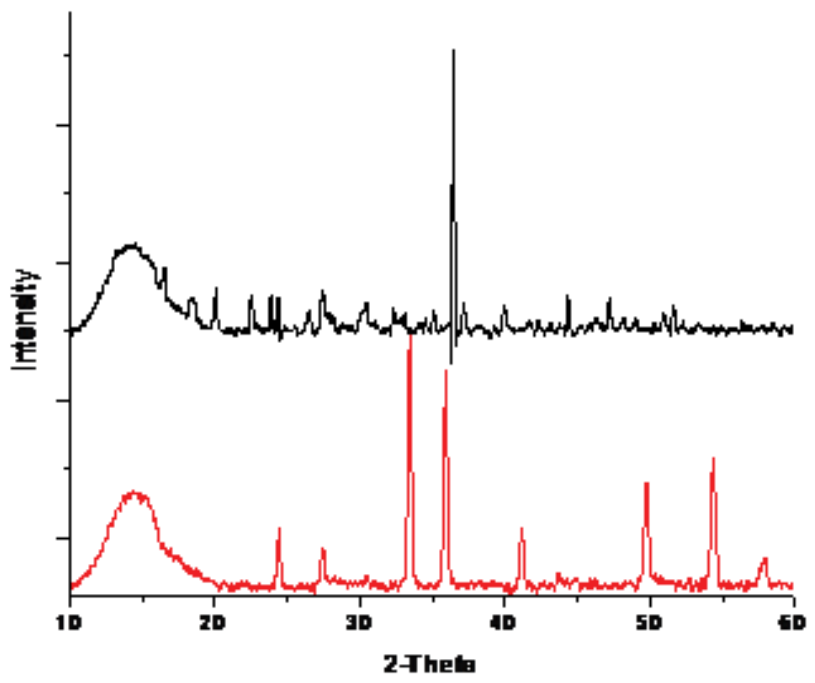

Fig. 3: XRD spectra of raw Annabethi and Annabethi chenthuram

- Raw Annabethi; - Annabethi chenthuram

titanium and zinc. Similarly, XRF characterization was done for related vanga Bhasma ${ }^{[25]}$.

SEM image of the raw Annabethi showed the presence of small particles placed over smooth planes (fig. 4). The size of those particles was found to be more than $100 \mathrm{~nm}$. SEM analysis of Annabethi chenthuram showed the presence of particles less than $100 \mathrm{~nm}$. However the particles are aggregated and approximately spherical in shape. During the preparation of Annabethi chenthuram from raw Annabethi, formation of nanoparticles with the particle size less than $100 \mathrm{~nm}$ was noticed (fig. 4) and our results are in agreement with earlier reports ${ }^{[23,25]}$.
Particle size distribution of raw Annabethi and Annabethi chenthuram was determined by the Microtrac particle size analyser that uses three precisely placed red laser diodes. The average particle size of raw Annabethi was $85 \mu \mathrm{m}$ whereas in the case of Annabethi chenthuram (after putam) it was found to be $71 \mu \mathrm{m}$. The particle size was reduced during the conversion of raw Annabethi into Annabethi chenthuram. The same analysis was already noted in previous studies in Kasisa Bhasma, Kanta chenthuram and Arka Lavana ${ }^{[21,22,26] . ~}$

In the present study, we have prepared the Siddha formulation Annabethi chenthuram and analysed its physicochemical and structural characteristics. Physicochemical values for the raw, detoxified and final product were determined and reported for the first time, which could be useful in quality control steps.

FTIR spectra of Annabethi chenthuram revealed that the iron content was increased compare to the raw drug. XRF analytical data confirmed the presence of iron and iron oxide in large portion. XRD pattern explored the formation of crystalline compound which is again due to the impact of incineration processes. The SEM report and particle size analysis data indicated that the raw drug obtained was in nanometer size. From the present study, it is clear that Annabethi chenthuram preparation method prescribed in Siddha system involves scientific

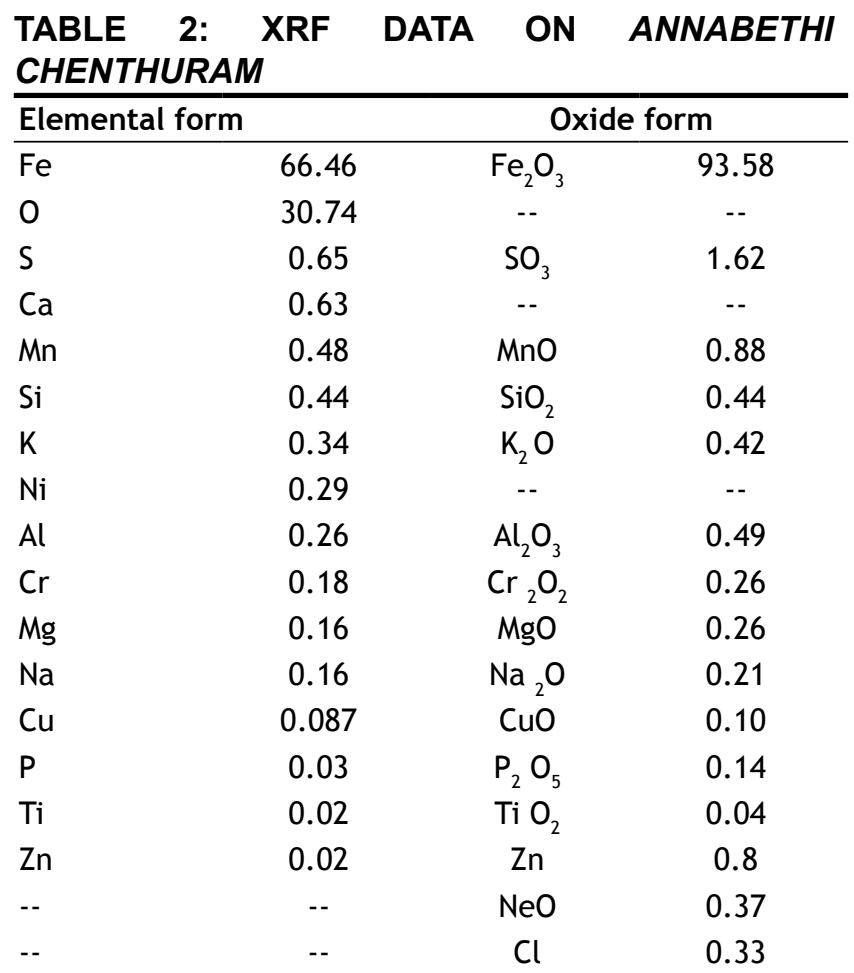

Level of oxide form of iron $\left(\mathrm{Fe}_{2} \mathrm{O}_{3}\right)$ was found to be higher in Annabethi chenthuram when compared to elemental form 

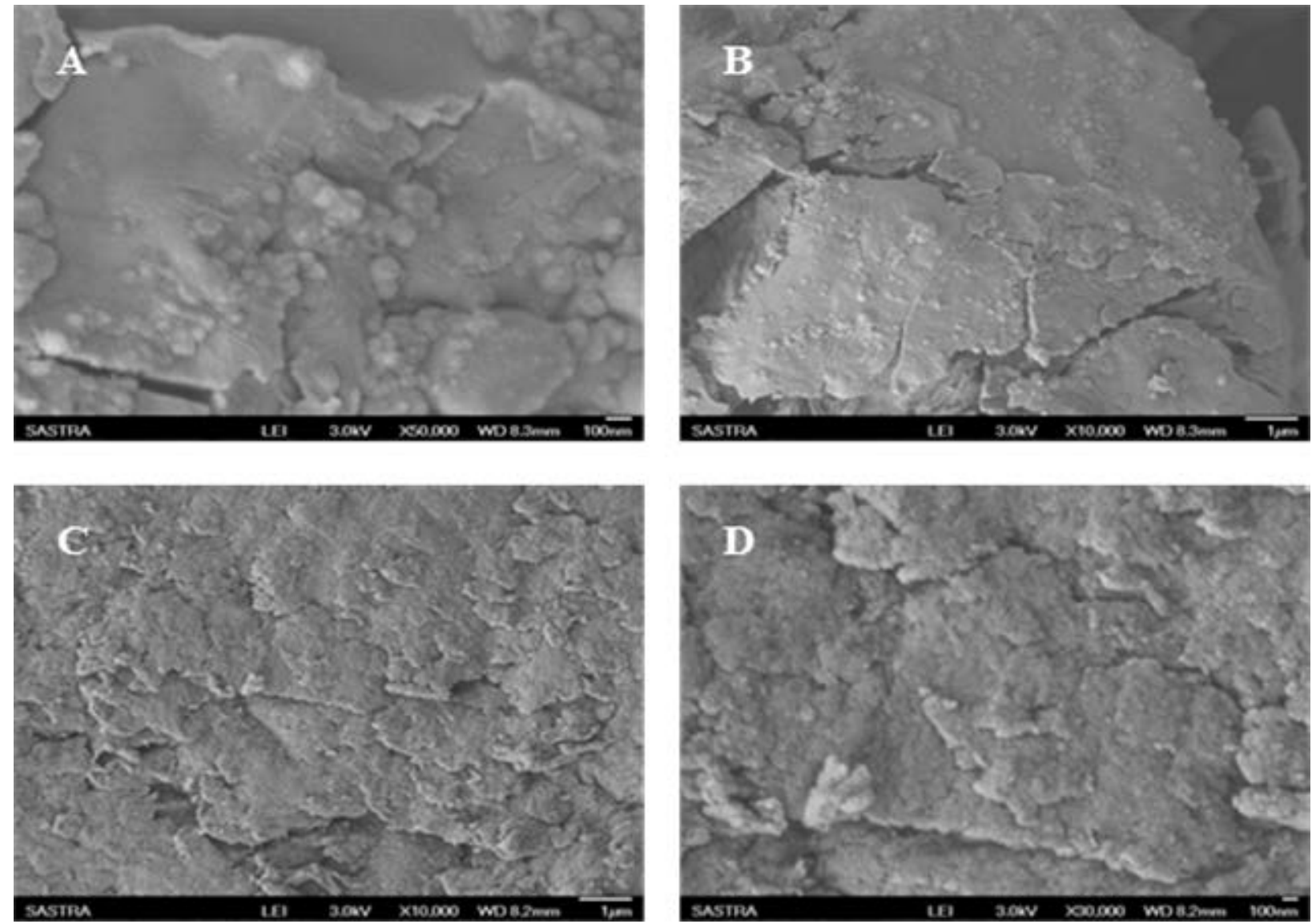

Fig. 4: SEM images of raw and final drug of Annabethi

Raw Annabethi: 50000 magnification (A) and $10000 X$ magnification (B). Final drug of Annabethi: 10 000X magnification (C) and $30000 X$ magnification (D)

and systematic detoxification processes with enhanced therapeutic potential.

\section{Acknowledgements:}

Authors thank the Honourable Vice Chancellor of SASTRA University for constant encouragement and support to carry out this research work.

\section{Conflict of interest:}

The authors declare that they have no conflict of interest.

\section{Financial support and sponsorship:}

Nil.

\section{REFERENCES}

1. Thyagarajan R. Gunapadam Thaathu Jeeva Vaguppu, 4th ed. Chennai: Department of Indian Medicine and Homeopathy; 2004.

2. Ganguli MN, Singh RK, Jamadaghi SB, Mitra A, Upadhyay SN, Hazra J. Toxicological evaluation of kasisabhasma, an Ayurvedic organa metallic preparation. Int J Res Ayurveda Pharm 2012;3:381-6.
3. Nadkarani KM, Nadkarani AK. Indian Materia Medica. 3rd ed. Mumbai: Popular Prakash; 2005.

4. Anonymous. The Siddha Formulary of India. New Delhi: Ministry of Health and Family Welfare, Department of AYUSH, Government of India; 1992.

5. Kuppusamy Mudhaliyar KN. Siddha maruthuvam (Pothu). 7th ed. Chennai: Department of Indian Medicine and Homeopathy; 2007.

6. Murugesa Mudalier KS, Gunapadam Mooligai Vaguppu. 2nd ed. Chennai: Tamilnadu Siddha Medical Council; 2008.

7. Anonymous. Formulary of Siddha Medicines. Chennai: Indian Medical Practitioners Cooperative Pharmacy and Stores Ltd.; 1989.

8. Kuppusamy Mudaliyar KN, Uthamarayan KS. Siddha vaithiya thirattu. Chennai: Tamilnadu Siddha Medical Council; 1998.

9. Narayanaswami V. Pharmacopoeia of Hospital of Indian Medicine. Chennai: Tamilnadu Siddha Medical Board; 1995.

10. Nishakumari PR, Dinesh Nayak J, Sathyanarayana B. Comparative antimicrobial study of shuddha Kasisa and Kasisa Bhasma. Int Ayur Med J 2016;4:579-83.

11. Palbag S, Saha D, Gautam DNS. Toxicity studies of ironcontaining Ayurvedic drug Kasisa Bhasma. BLDE Univ J Health Sci 2016;1:39-43.

12. Yogita S, Tiwari GN, Sujata S, Manoj S. Therapeutic role of Gomed-Mandur-Kasisa Bhasma compound in clinical management of sickle cell anaemia. J Pharm Sci Innov 2014; 3:459-62. 
13. Anonymous. Sarakku Suthi Seimuraigal. 1st ed. Chennai: Department of Indian System of Medicine and Homeopathy; 2008.

14. The Ayurvedic Pharmacopoeia of India. Part I, Volume IV, New Delhi: Ministry of Health and Family Welfare, Department of AYUSH; 2004.

15. http://apps.who.int/iris/itstream/10665/41986/1/9241545100. pdf.

16. Joshi S, Aeri V. Practical Pharmacognosy, 1sted. New Delhi: Frank Bros and Co. Ltd; 2009. p. 290-3.

17. Das PC. Text Book of Medicine. 3rd ed. Calcutta: Current Books International; 1991.

18. Anonymous. Parameters for quality assessment of Ayurveda and Siddha drugs. Part A. New Delhi: Central Council for Research in Ayurveda and Siddha, Department of AYUSH; 2005.

19. Anonymous. Pharmacopoeial Standards for Ayurvedic Formulations. New Delhi: Central Council for Research in Ayurveda and Siddha, Ministry of Health and Family Welfare; 1987.
20. Akila B, Manickavasakam K, Shakila R. Chemical analysis of Gomutra Silasathu Parpam. Int J Drug Delivery 2014;6:88-93.

21. Yadav S, Debnath M. Pharmaceutical and physicochemical study of Kasisa Bhasma. Indian J Ethno-Phytopharm 2016;2:43-9.

22. Geetha Sudeer R, Amrutha P, Brindha P, Ramanathan V. What roles do herbs play in Kantacenturam: An iron oxide based herbo-mineral Siddha drug formulations? Indian J Tradit Know 2015;14:433-9.

23. Rajalakshmi P, Devanathan R, Brindha P. Analytical studies on Muthuchippi Parpam. J Pharm Res 2010;3:2366-70.

24. Devanathan R, Rajalakshmi P, Brindha P. Chemical standardisation of Varatika Bhasma. Int J Cur Pharm Res 2010:2;12-6.

25. Saraswathi A, Ruckmani S, Devi AM, Ariyanathan S. Chemical analysis of Vanga Bhasma. Int J Res Ayur Pharm 2013;4:676-9.

26. Devanathan R, Niraimathi KL, Karunanidhi M, Brindha P. Comparative evaluation of Arka Lavana - An Ayurvedic herbomineral formulation. Int J Pharm Clin Res 2013;5:37-42. 